\title{
PERANCANGAN SISTEM INFORMASI PEMESANAN RENDANG TELUR PADA TOKO IIM JL.ADINEGORO LUBUK BUAYA PADANG MENGGUNAKAN BAHASA PEMROGRAMAN PHP DAN DATABASE MYSQL
}

\author{
Rahmat $^{1)}$ Dhio Saputra, S.Kom, M.Kom ${ }^{2)}$ Rima Liana Gema, S.Kom, M.Kom ${ }^{3)}$ \\ Email : ${ }^{1)}$ rahmatdamaik@gmail.com \\ Sistem Informasi, Universitas Putra Indonesia "YPTK” Padang, Sumatera Barat \\ Email : ${ }^{2)}$ Dhiosaputra@upiyptk.ac.id \\ Sistem Informasi, Universitas Putra Indonesia "YPTK" Padang, Sumatera Barat \\ Email : ${ }^{3)}$ rimalianagema@upiyptk.ac.id \\ Sistem Informasi, Universitas Putra Indonesia “YPTK” Padang, Sumatera Barat
}

\begin{abstract}
Abstrak Internet Teknologi sudah terbukti merupakan salah satu media informasi yang efektif dan efisien dalam penyebaran informasi yang dapat diakses oleh siapa saja, kapan saja dan dimana saja. dengan perkembangan aplikasi web yang semakin pesat sejak munculnya teknologi internet sangat membantu dalam kemudahan serta kecepatan pengiriman, penyampaian dan penerimaan informasi. Selama ini, Toko Iim bergerak dalam bidang pemesanan makanan yaitu rendang telur khas minangkabau, promosi yang ada masih menggunakan fasilitas kertas, brosur, dan fasilitas lainya yang sejenis. Hambatan-hambatan tersebut yang membuat kurang efektifnya promosi produk, serta pelanggan yang ingin melihat informasi makanan rendang telur yang ada pada Toko Iim harus datang langsung ke alamat.Oleh karena itu, penulis tertarik untuk merancang suatu aplikasi promosi dan pemesananrendang telur berbasis web. Sehingga bisa memenuhi keinginan pengguna informasi yang menginginkan kecepatan waktu.
\end{abstract}

\section{Kata Kunci : E-Commerce, Web, Internet, Rendang}

\section{Pendahuluan}

Rendang telur adalah makanan asli khas masyarakat minangkabau banyak diminati oleh semua orang terutama yaitu keluarga dan orang sekitar juga masyarakat luar daerah, dan berbeda kota pun banyak yang menyukai rendang telur khas minang ini, selain itu juga dapat di konsumsi untuk persediaan makanan yang tak terduga seperti hal nya mahasiswa kesulitan uang untuk sarapan hanya tinggal menyantap rendang telur dan di lengkapi dengan nasi sangat menggugah selera karena rendang telur bersifat tahan juga aman untuk di konsumsi dan murah dapat menghemat pengeluaran yang tak menentu saat nya.

Rendang telur khas minang ini banyak peminat nya baik dari dalam daerah maupun luar daerah dan juga dari luar kota dan sampai Negara luar pun ada yang menyukai rendang telur asli khas masyarakat minangkabau ini,karena itulah internet sangat penting dalam proses pemesanan barang untuk mempermudah kegiatan dan menghemat waktu agar kepercayaan konsumen dapat terjaga dengan sepenuh nya.

Oleh sebab itu sistem yang berjalan pada toko IiM masih menggunakan cara yang manual contohnya dalam pengelohan data dan pencarian data pemesanan, pembuatan laporan yang kurang teliti membutuhkan waktu yang lama. akibatnya sering kali terjadi kesalahan dalam pencatatan pemesanan. 


\section{Landasan Teori}

\subsection{Konsep Dasar Sistem Informasi}

Informasi merupakan suatu hal yang sangat dibutuhkan dalam suatu organisasi ataupun instansi. Informasi juga merupakan kebutuhan bagi manajemen di dalam pengambilan keputusan. Suatu sistem informasi berbasis website sekolah merupakan salah satu bentuk media publikasi elektronik yang dapat digunakan sebagai salah satu 'senjata' bagi sekolah yang ingin menunjukan jati diri mereka pada masyarakat luas, sekaligus sebagai media informasi bagi orang-orang luar yang ingin mengetahui lebih lengkap seluk beluk tentang sekolah tersebut. Di sisi lain, website sekolah juga bisa dijadikan sebagai ajang promosi sekolah untuk memikat para calon santriwansantriwati saat tahun ajaran baru. Menurut Riyadi, Retnandi, Deddy (2012).

\subsection{Pengertian Sistem}

Sistem didefinisikan sebagai kumpulan prosedur yang saling berkaitan dan saling terhubung untuk melakukan suatu tugas bersama-sama. Secara garis besar, sebuah sistem terdiri dari tiga komponen utama. Ketiga komponen tersebut mencangkup software, hardware, dan brainware. Ketiga komponen tersebut saling berkaitan.

\subsection{Karakteristik Sistem}

Sistem mempunyai beberapa karakteristikatau sifat-sifat tertentu, antara lain

1. Komponen Sistem (Component)

Suatu sistem terdiri dari komponen-komponen yang saling berinteraksi,yang artinya saling bekerja sama membentuk suatu kesatuan

2. Batasan Sistem (Boundary)

Merupakan daerah yang membatasi suatu sistem dengan sistem yang lain atau dengan lingkungan kerjanya. Batas suatu sistem menunjukan ruang lingkup (scope) dari sistem tersebut.

3. Lingkungan Luar Sistem (Environment)Suatu sistem yang ada di luar dari batasan-batasan sistem yang dipengaruhi oleh beberapa operasi sistem.

4. Penghubung Sistem (Interface)Suatu media (penghubung) antara satu subsistem dengan subsistem lain nya yang membentuk satu kesatuan,sehingga sumber-sumber daya mengalir dari subsistem yang satu ke subsitem yang lainnya.dengan kata lain ,melalui penghubung, output dari subsistem akan menjadi input bagi subsistem lainnya.

5. Masukan Sistem (Input)

Energi yang masuk ke dalam sistem yang dapat yang dapat berupa masukan yaitu energi yang dimasukkan supaya sistem dapat beroperasi atau masukan sinyal yang merupakan energi yang diproses untuk menghasilkan suatu luaran.

6. Keluaran Sistem (Output)

Hasil energi yang diolah dan diklasifikasikan menjadi keseluruhan yang berguna dan sisa pembuangan.

7. Pengolahan Sistem (Process)

suatu sistem dapat mempunyai suatu bagianpengolahan yang akan mengubah masukan menjadi keluaran.

8. Sasaran Sistem $($ Object $)$

Sasaran dari sistem sangat menentukan sekalimasukan yang dibutuhkan sistem dan keluaran yang akan di hasilkan sistem. Suatu sistem dikatakan berhasil bila mengenai sasaran atau tujuannya . (Hamim Tohari ; 2014,2)

\subsection{Pengertian Informasi}

Informasi merupakan suatu hal yang sangat dibutuhkan dalam suatu organisasi ataupun instansi. Informasi juga merupakan kebutuhan bagi manajemen di dalam pengambilan keputusan. Suatu sistem informasi berbasis website sekolah merupakan salah satu bentuk media publikasi 
elektronik yang dapat digunakan sebagai salah satu 'senjata' bagi sekolah yang ingin menunjukan jati diri mereka pada masyarakat luas, sekaligus sebagai media informasi bagi orang-orang luar yang ingin mengetahui lebih lengkap seluk beluk tentang sekolah tersebut. Di sisi lain, website sekolah juga bisa dijadikan sebagai ajang promosi sekolah untuk memikat para calon santriwansantriwati saat tahun ajaran baru. Menurut Riyadi, Retnandi, Deddy (2012).

\subsection{Pengertian Sistem Informasi}

Sistem Informasi (SI) adalah kombinasi dari teknologi informasi dan aktivitas orang yang menggunakan teknologi itu untuk mendukung operasi dan manajemen. Dalam arti yang sangat luas, istilah system informasi yang sering digunakan merujuk kepada interaksi antara orang, proses algoritmik, data, dan teknologi. Dalam pengertian ini, istilah ini digunakan untuk merujuk tidak hanya pada penggunaan sistem pengolahan database Rawat-Inap pada Rumah Sakit Umum Aisyiyah Padang, dengan menggunakan komputer diharapkan dapat organisasi Teknologi Informasi dan Komunikasi (TIK). MenurutAnisya (2013).

\section{Analisa dan hasil}

\subsection{Analisa Sistem}

Analisa sistem dapat didefinisikan sebagai sebuah kegiatan yang dilakukan untuk mengetahui masalah-masalah, hambatan-hambatan atau kendala-kendala yang terjadi pada yang sistem yang sedang berjalan atau sedang digunakan agar dapat diperbaiki. Biasanya analisa sistem dilakukan sebelum perancangan sistem, hal ini dilakukan untuk mempermudah kita dalam melakukan kegiatan perancangan nantinya. Pada tahap inilah kebutuhan akan pemakai sistem didefinisikan sebelum akhirnya akan dirancang menjadi sebuah sistem utuh yang siap digunakan. Analisa sistem dilakukan agar penemuan masalah yang ada, dapat diketahui penyebab, sehingga dari analisa masalah itu dapat dirumuskan pemecahan masalah.

\subsection{Perancangan Sistem Menggunakan UML}

Unified Modelling Language (UML) adalah sebuah "bahasa" yang telah menjadi standar dalam industri untuk visualisasi, merancang dan mendokumentasikan sistem piranti lunak.UML menawarkan sebuah standar untuk merancang model sebuah sistem.Dengan menggunakan UML kita dapat membuat model untuk semua jenis aplikasi piranti lunak, dimana aplikasi tersebut dapat berjalan pada piranti keras, sistem operasi dan jaringan apapun, serta ditulis dalam bahasa pemrograman apapun. Adapun UML yang dirancang dalam pembuatan sistem ini sebagai berikut:

\subsection{Use Case Diagram}

Use case Diagram, menggambarkan sekelompok Use case dan aktor yang disertai dengan hubungan diantaranya. Use case diagram dapat sangat membantu bila kita sedang menyusun requirement sebuah sistem, mengkomunikasikan rancangan dengan klien dan merancang test case untuk semua feature yang ada pada sistem. Berikut ini adalah use case diagram dari sistem penjualan dan pemesanan Toko Iim, dapat dilihat pada gambar 3.2. : 


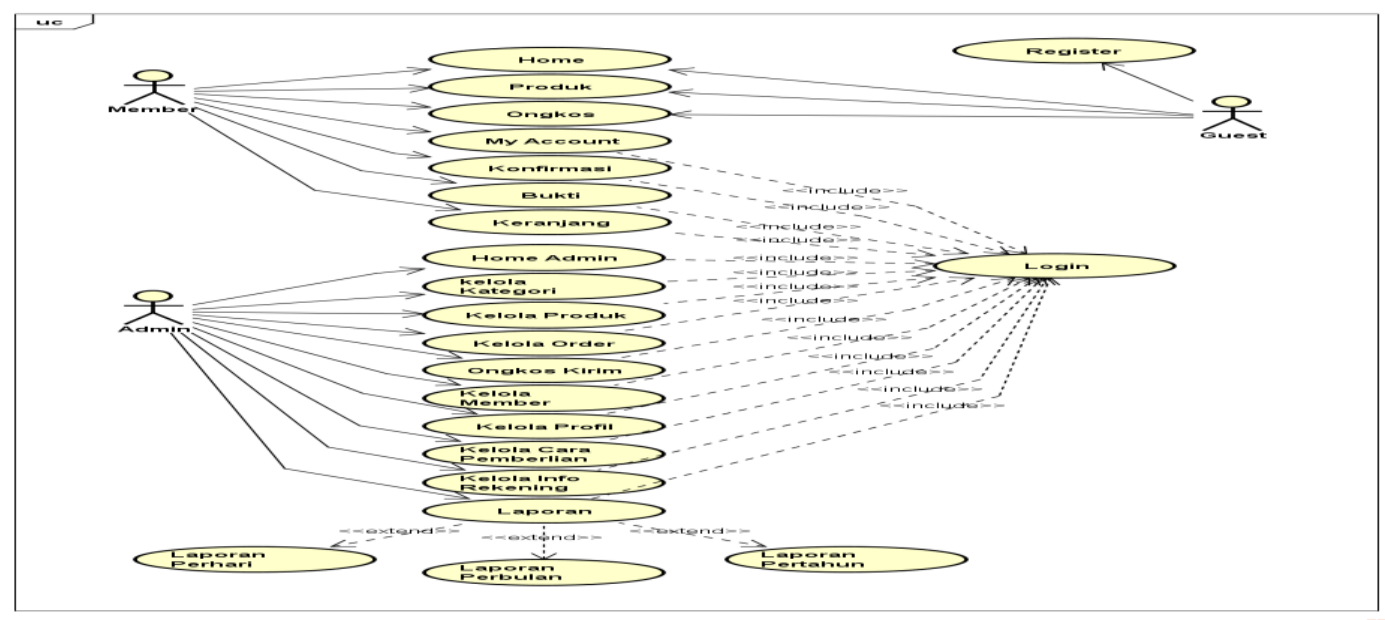

Gambar 3.2 Use CaseDiagram

\section{Class Diagram}

Class diagram menampilkan eksistensi atau keberadaan dari class-class dan hubungan (relationship) dalam desain logikal dari sebuah sistem. Class adalah sebuah spesifikasi yang jika diinstansiasi akan menghasilkan sebuah objek dan merupakan inti dari pengembangan dan desain berorientasi objek. Class menggambarkan keadaan (atribut/properti) suatu sistem, sekaligus menawarkan layanan untuk memanipulasi keadaan tersebut (metoda/fungsi). Berikut ini adalah class diagram dari sistem penjulan dan pemesanan Toko Iim, dapat dilihat pada gambar 3.3:

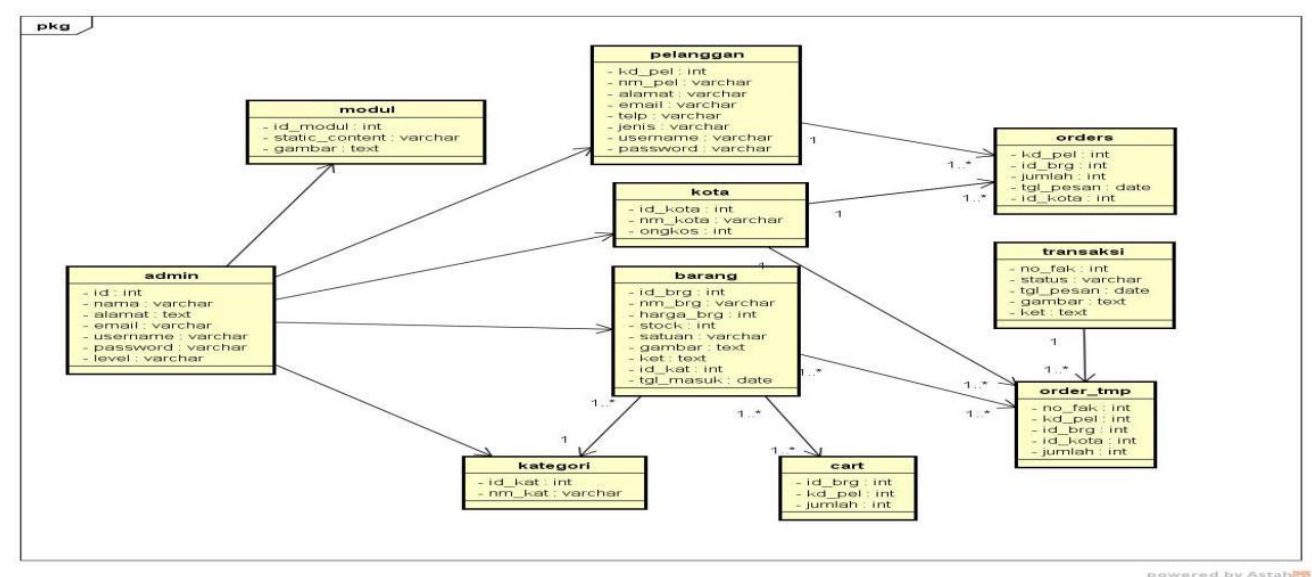

Gambar 3.3 ClassDiagram

\section{Activity Diagram Admin}

Activity Diagram Admin terlihat pada gambar 3.9 dibawah ini : 
UPI YPTK Jurnal KomTekInfo Vol. 5, No. 1, Juni 2018, Hal.96-109 ISSN :2356-0010 | eISSN :2502-8758 Copyright@2018 by LPPM UPI YPTK Padang

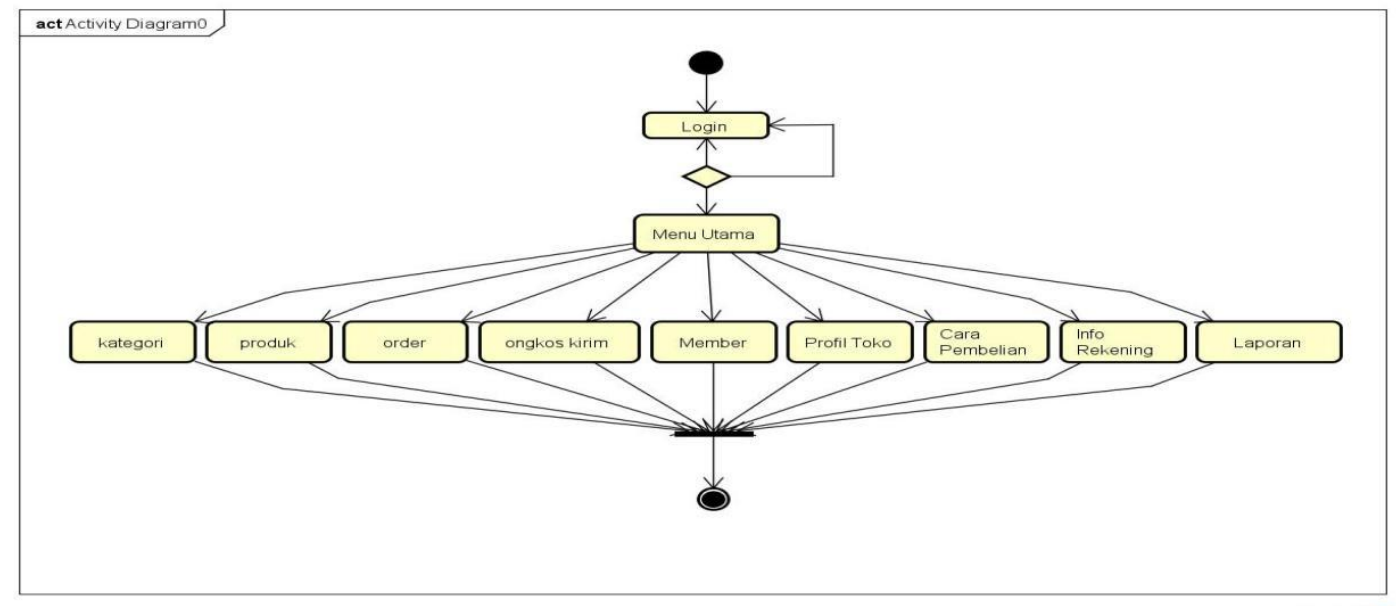

\section{Gambar 3.9 Activity DiagramAdmin}

\section{Activity Diagram Member}

Activity Diagram Member terlihat pada gambar 3.10 dibawah ini :

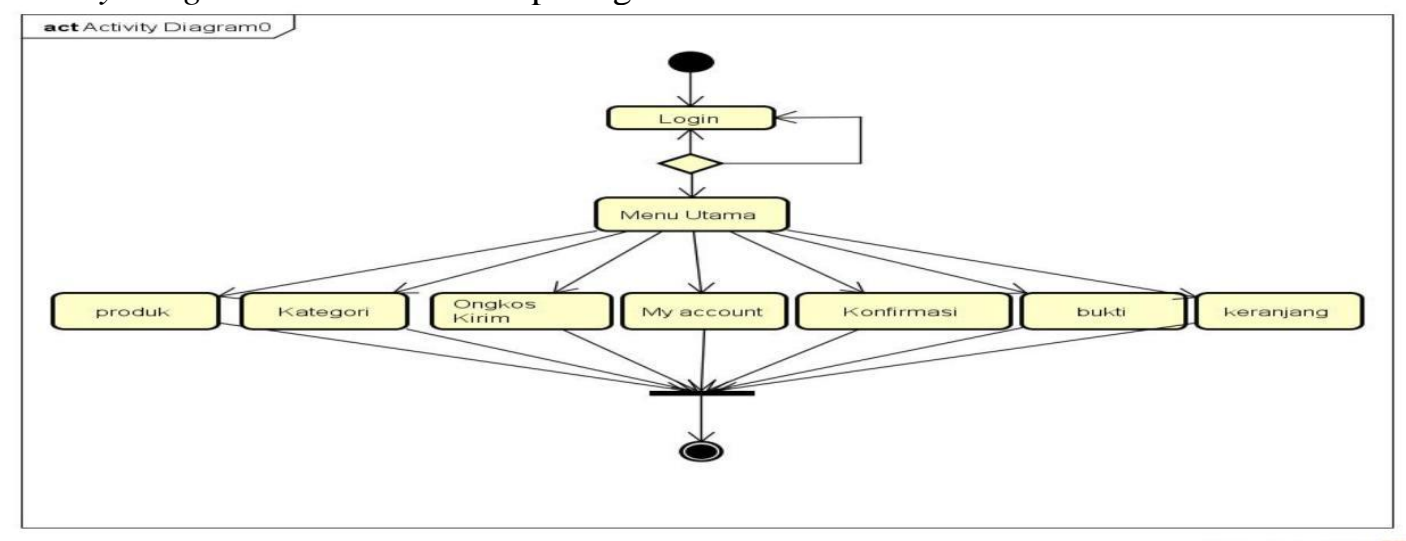

Gambar 3.10 Activity DiagramMember

\section{Activity Diagram Guest}

Activity Diagram Guest terlihat pada gambar 3.11 dibawah ini :

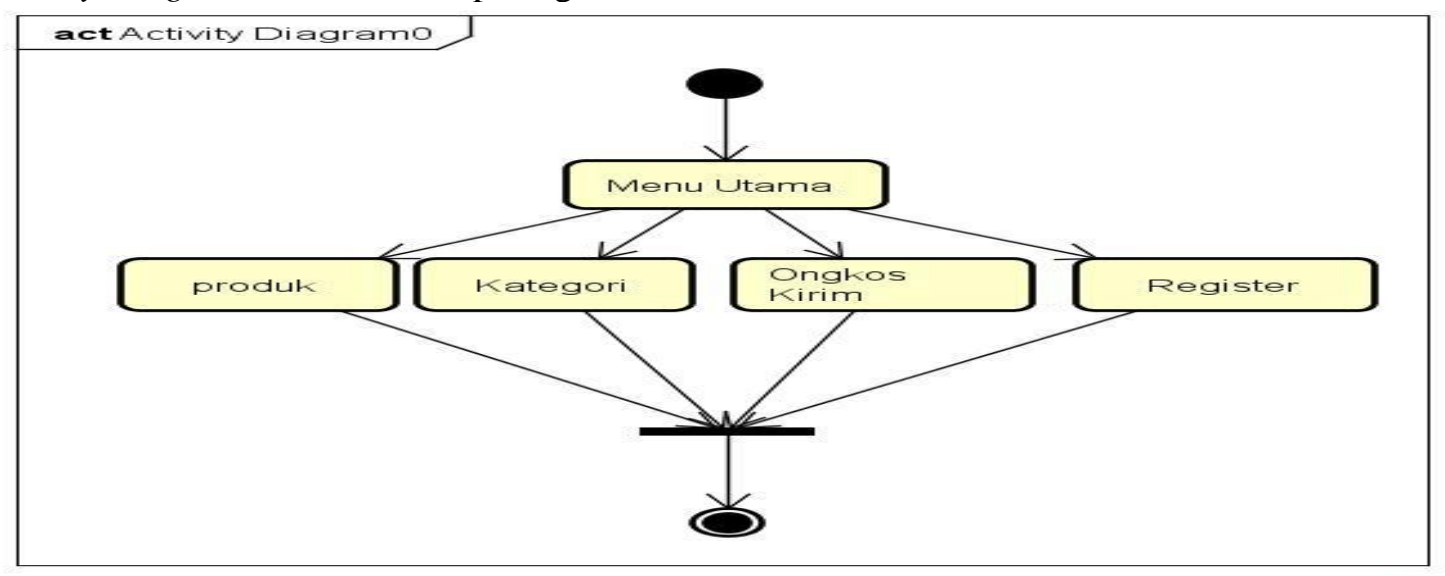

Gambar 3.11 Activity DiagramGuest

Sequence Diagram Login Member 
UPI YPTK Jurnal KomTekInfo Vol. 5, No. 1, Juni 2018, Hal.96-109 ISSN :2356-0010 | eISSN :2502-8758 Copyright $@ 2018$ by LPPM UPI YPTK Padang

Sequence Diagram Login Member untuk melakukan login pada aplikasi penjualan dan pemesanan terlihat pada gambar 3.4 dibawah ini :

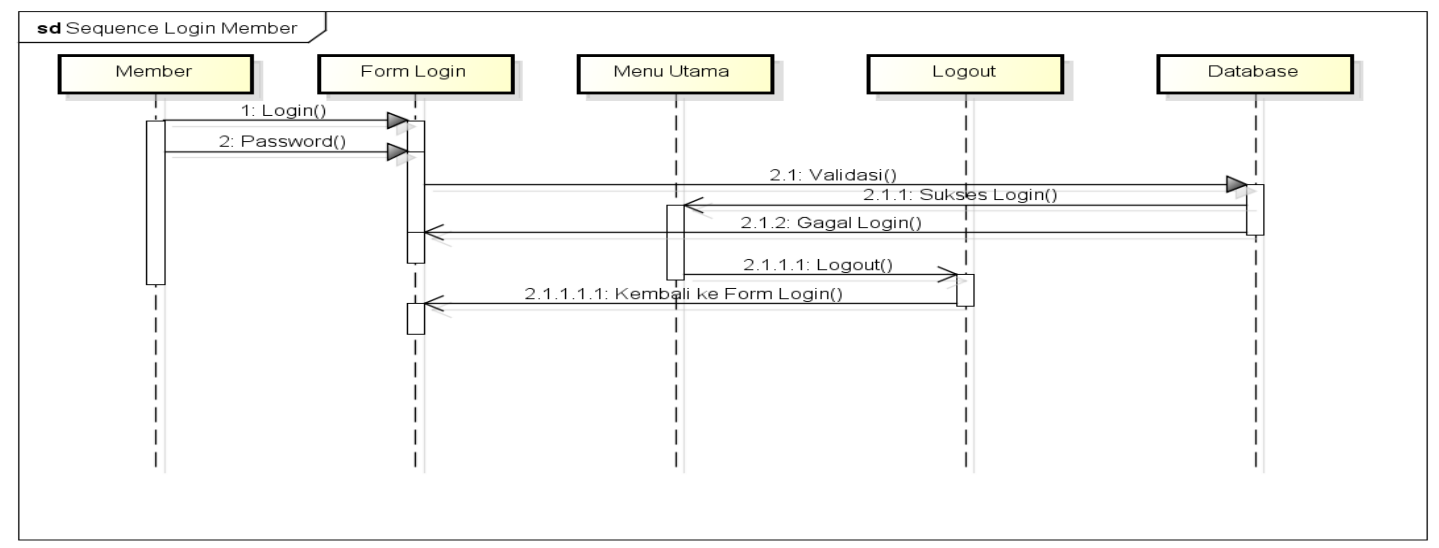

\section{Gambar 3.4 Sequence Diagram LoginMember}

\section{Sequence Diagram Produk}

Sequence Diagram Produk menjelaskan urutan langkah-langkah yang dilakukan member untuk menggunakann menu Produk.3.5 di bawah ini:

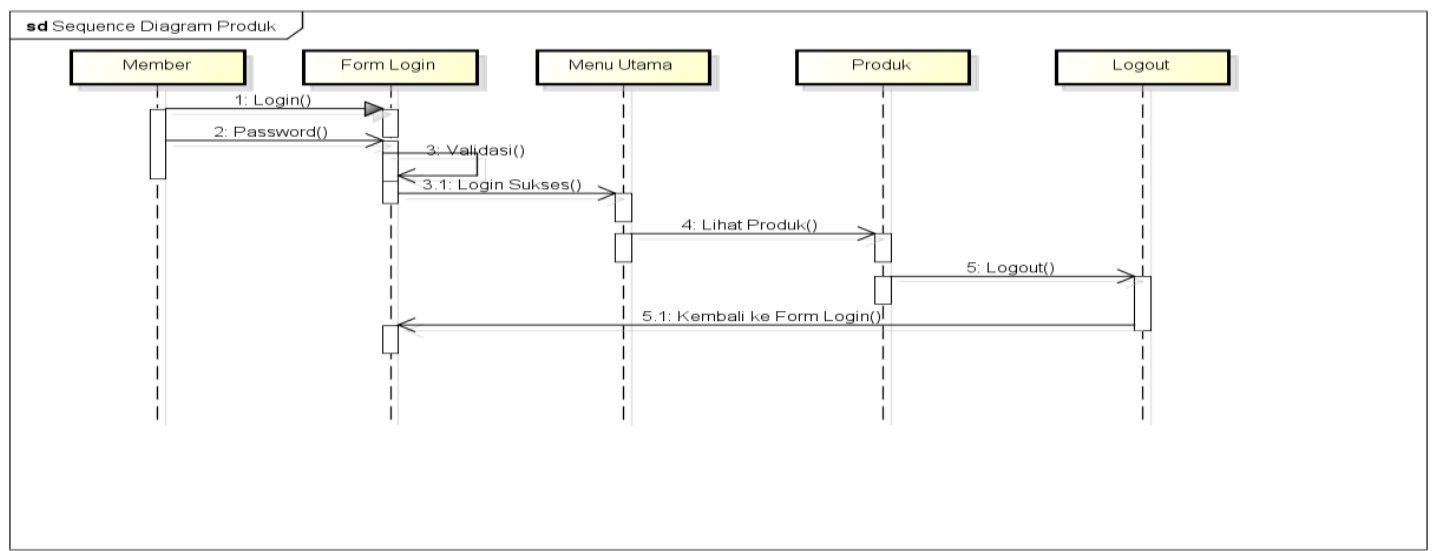

\section{Gambar 3.5 Sequence Diagram Produk}

\section{Sequence Diagram Login Admin}

Sequence Diagram Login Admin menjelaskan urutan langkah-langkah yang dilakukan admin untuk login kedalam sistem. Berikut adalah Sequence Diagram Admin login yangdapat dilihat pada gambar 3.6. :

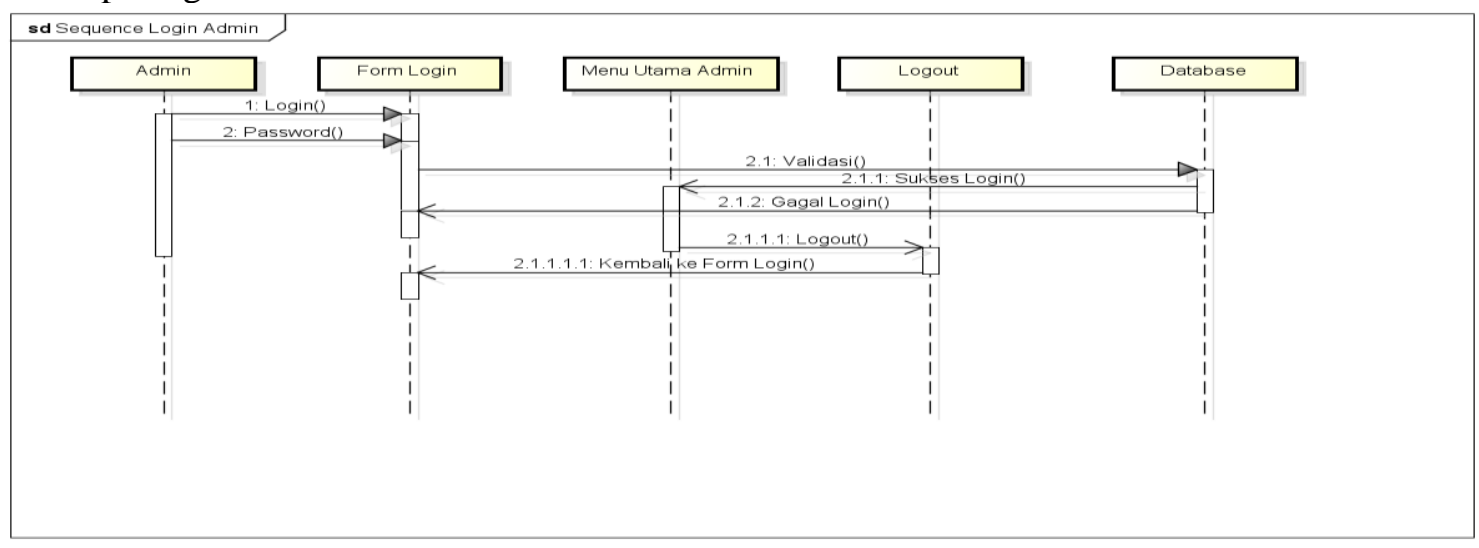




\section{Gambar 3.5 Sequence Diagram Login Admin}

\section{Sequence Diagram Konfirmasi Order}

Sequence Diagram Konfirmasi Order menjelaskan urutan langkah-langkah yang dilakukan admin untuk menggunakan menu order. Berikut adalah Sequence Diagram Konfirmasi Order yangdapat dilihat pada gambar 3.7. :

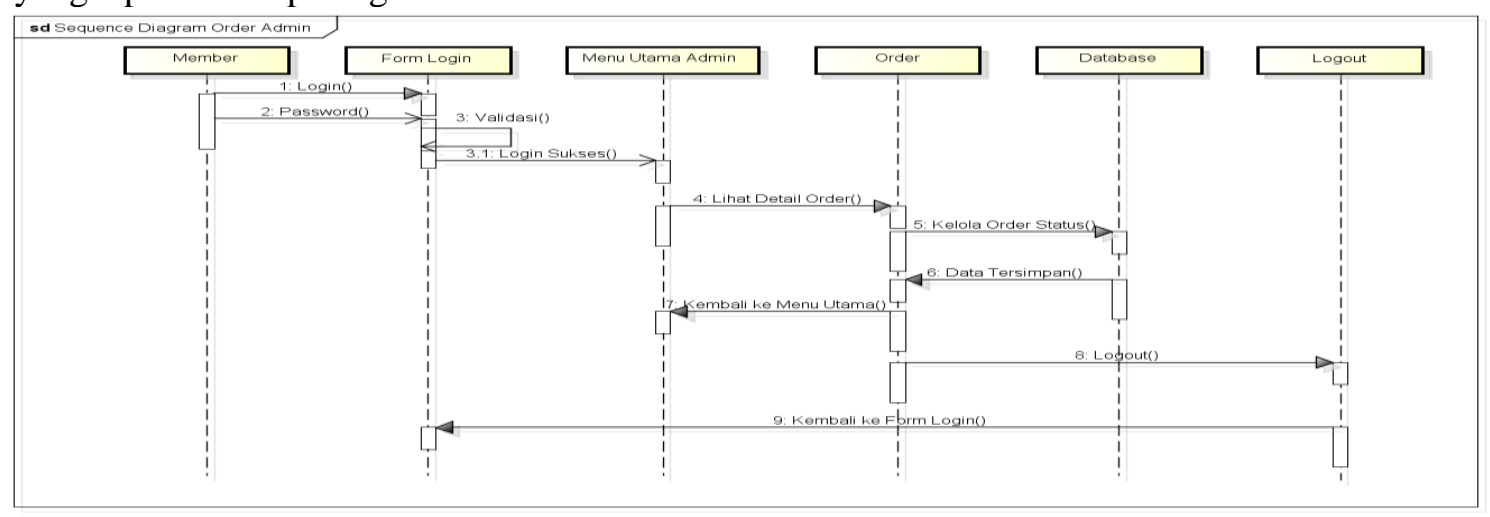

Gambar 3.7 Sequence Diagram Konfirmasi Order

\section{Sequence Diagram Konfirmasi Order}

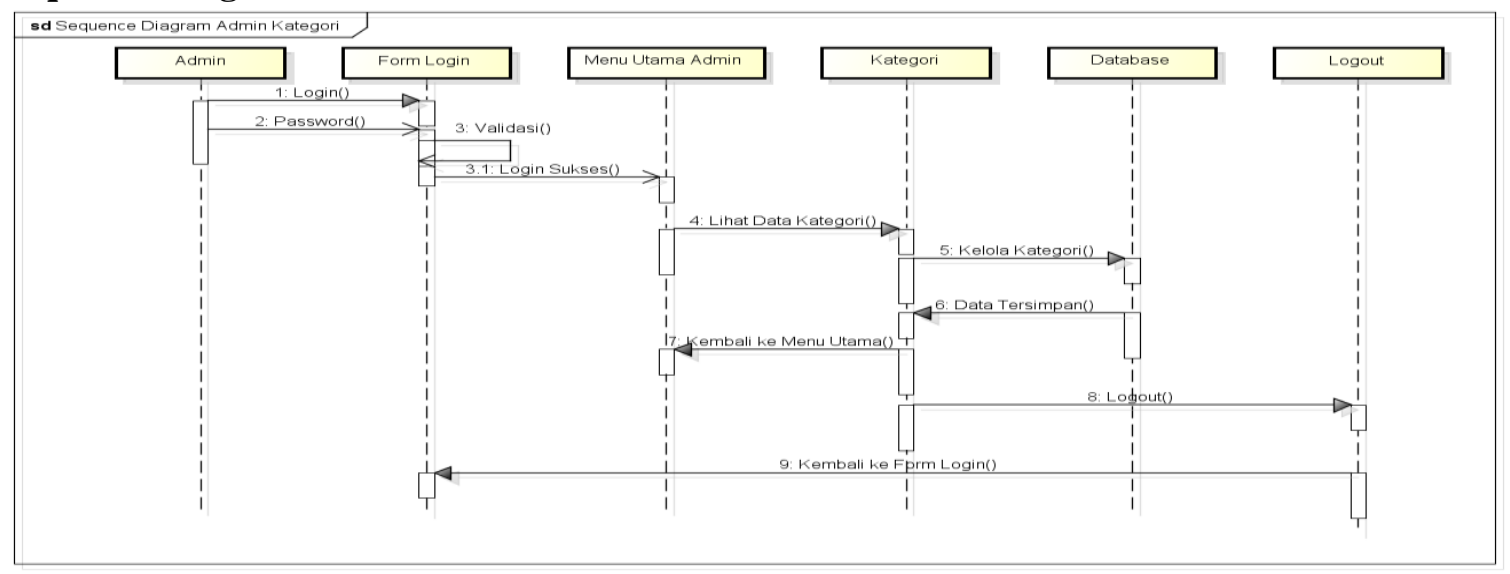

Gambar 3.8 Sequence Diagram Admin Kategori

\section{Implementasi dan Pengujian Sistem}

\section{Implementasi Sistem}

Implementasi sistem merupakan tahap meletakan sistem supaya siap untuk dioperasikan. Di dalam implementasi sistem ada beberapa tahap yang harus dilakukan diantaranya adalah menerapkan rencana implementasi, melakukan kegiatan implementasi dan tindak lanjut implementasi. Untuk melakukan atau mengimplementasikan program aplikasi yang telah dirancang, maka diperlukan sebuah alat bantu berupa komputer, yang mana untuk mengoperasikan komputer itu sendiri yang memerlukan tiga buah komponen pendukung seperti hardware, software dan brainware.

\section{Pengujian Instalasi Software}


UPI YPTK Jurnal KomTekInfo Vol. 5, No. 1, Juni 2018, Hal.96-109 ISSN :2356-0010 | eISSN :2502-8758 Copyright@2018 by LPPM UPI YPTK Padang

berisikan hasil program dan penjelasan program yang dibuat untuk mendukung sistem yang telah dirancang. Adapun software yang dibutuhkan dalam pengujian sistem antara lain software Xampp.

\section{Instalasi Software XAMPP}

Pada tahap awal kita lakukan installasi software xampp terlebih dahulu.

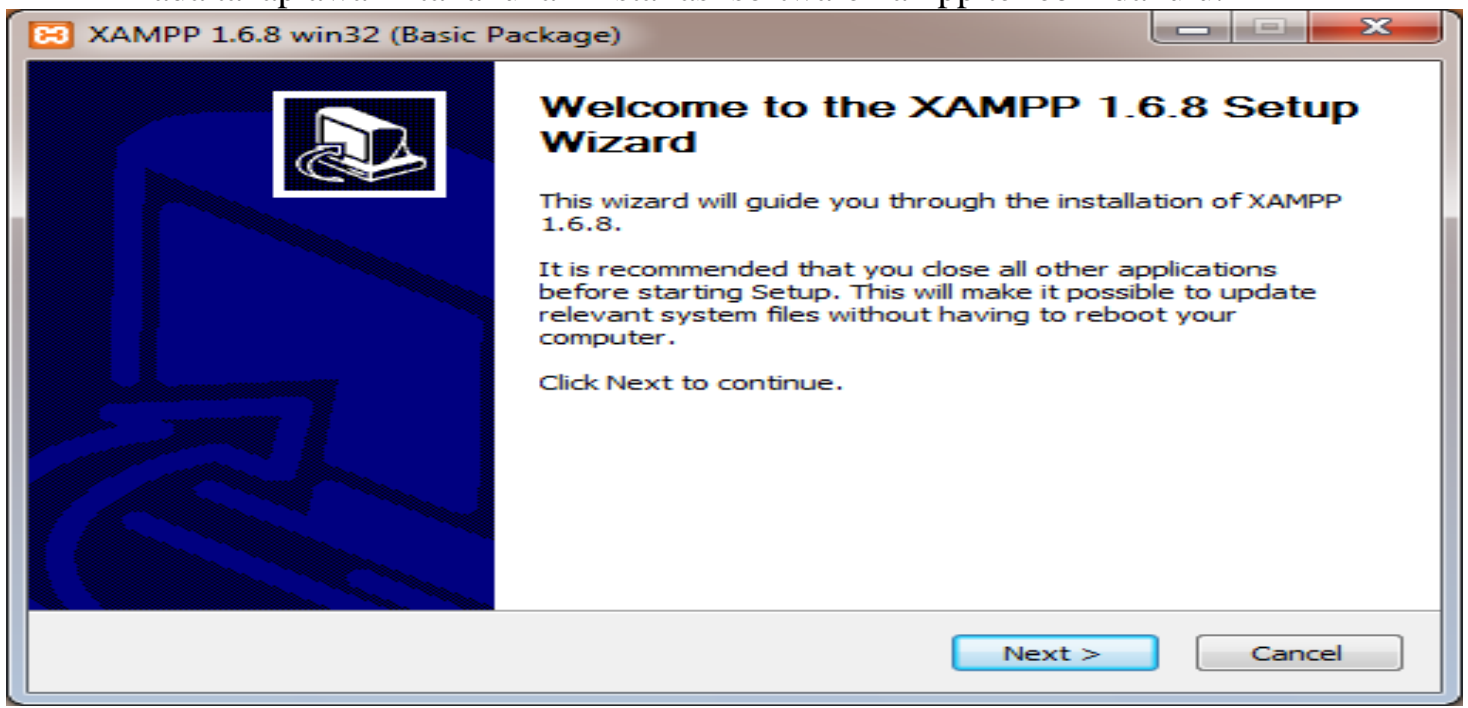

\section{Tampilan Menu Utama}

\section{Gambar 4.3 Tahap Installasi Software xampp}

Menu Utama merupakan tampilan menu utama pada saat membuka aplikasi. Pada halaman ini pengunjung juga dapat membuka halaman produk, registrasi dan link untuk login. Berikut gambar tampilan home yang dapat dilihat pada gambar 4.9 berikut ini:

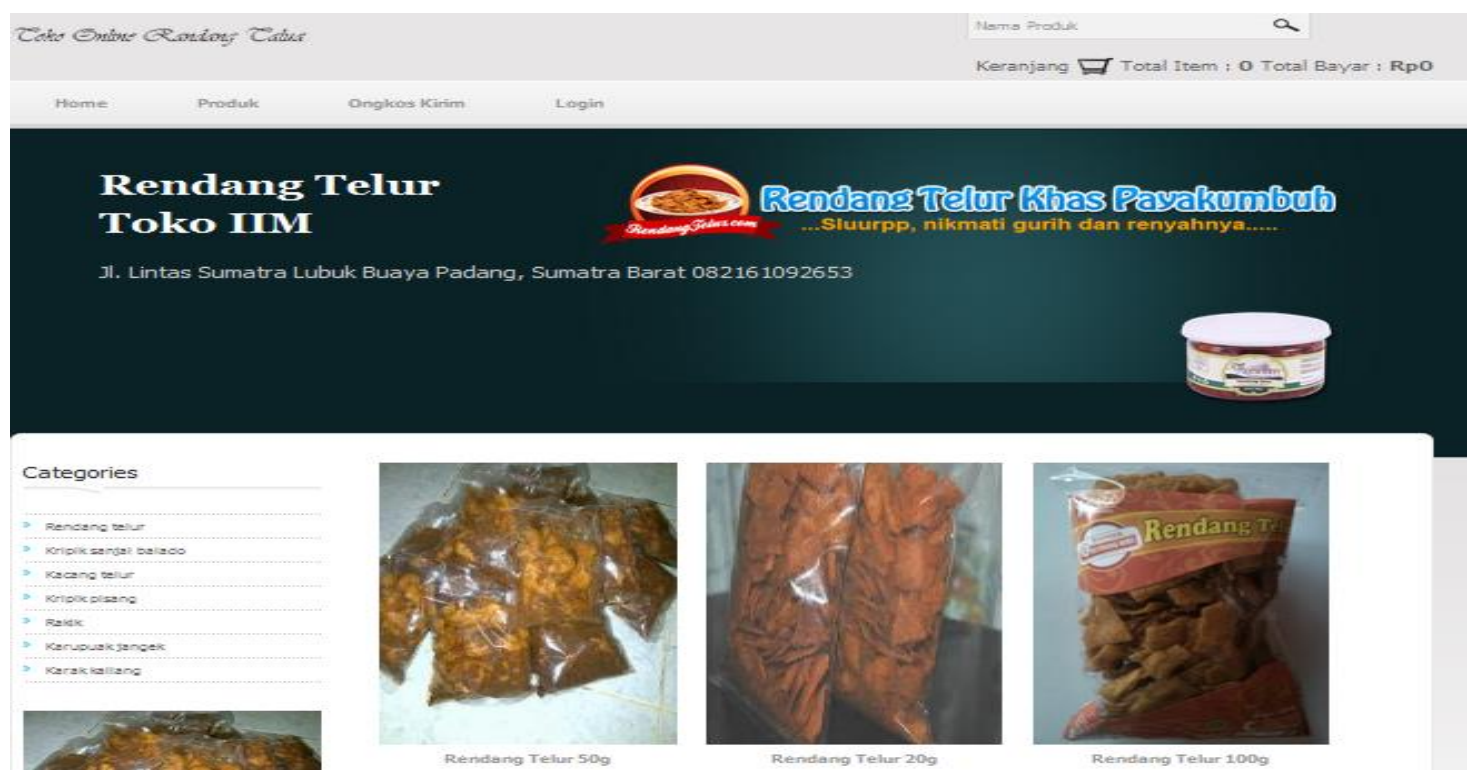

Gambar 4.9Tampilan Menu Utama

\section{Tampilan Produk}

Halaman produk berisi tentang produk-produk yang tersedia beserta informasi nama produk, harga produk. Berikut gambar tampilan produk toko Iim yang dapat dilihat pada gambar 4.10 berikut ini: 


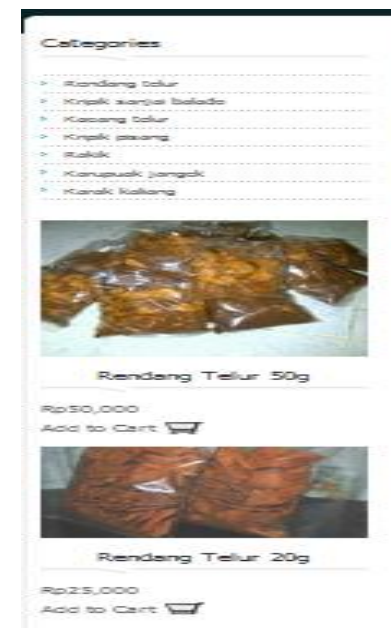

\section{Tampilan Registrasi}

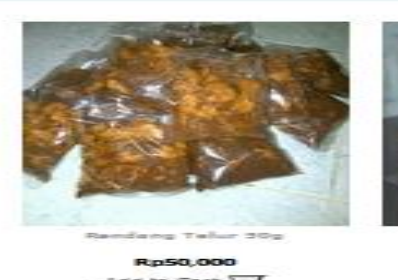

ressecos

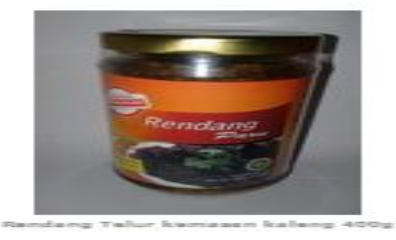

reonsadoo

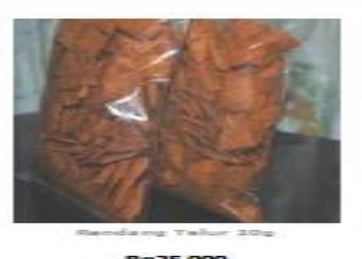

$\cos 200000$

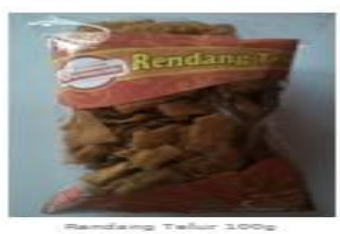

0000000

\section{Gambar 4.10 Tampilan Produk}

Halaman registrasi pelanggan harus mengisi data-data lengkap sehingga pelanggan bisa terdfatar dan memiliki username dan password untuk melakukan login. Berikut gambar tampilan registrasi yang dapat dilihat pada gambar 4.11 berikutini:

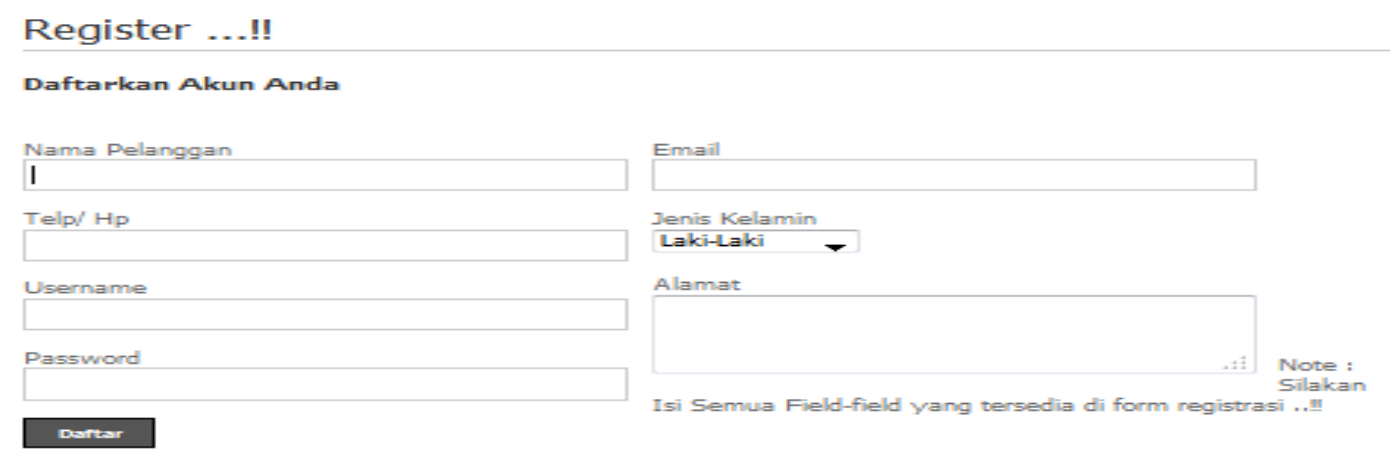

\section{Gambar 4.11 Tampilan Register}

\section{Tampilan Login}

Halaman login digunakan untuk pelanggan agar bisa masuk ke sistem dan melakukan pemesanan produk atau melihat produk yang tersedia. Berikut gambar tampilan login yang dapat dilihat pada gambar 4.12 berikut ini:

$$
\text { Login . . . !! }
$$

Login Dengan Username Dan Password

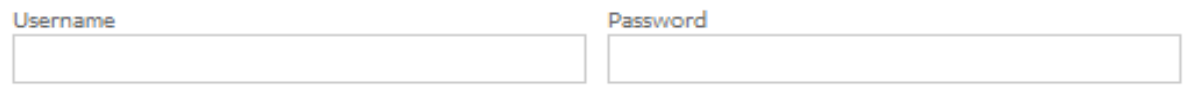

\section{Login}

Note : Bagi Yang sudah Memiliki Account Silakan login dengan Username Dan Password sedangkan bagi yang belum silakan daftar terlebih dahulu. Disini Reqister

\section{Tampilan Home Pelanggan}

\section{Gambar 4.12 Tampilan Login}

Halaman home pelanggan merupakan halaman utama pelanggan setelah login yang mana pelanggan dapat melakukan pembelian, keranjang belanja,rasa khas bumbu makanan yang 
UPI YPTK Jurnal KomTekInfo Vol. 5, No. 1, Juni 2018, Hal.96-109 ISSN :2356-0010 | eISSN :2502-8758 Copyright $@ 2018$ by LPPM UPI YPTK Padang

berbeda dan juga pembayaran, cetak bukti pemesanan, edit account. Berikut gambar tampilan home pelanggan yang dapat dilihat pada gambar 4.13 berikut ini:

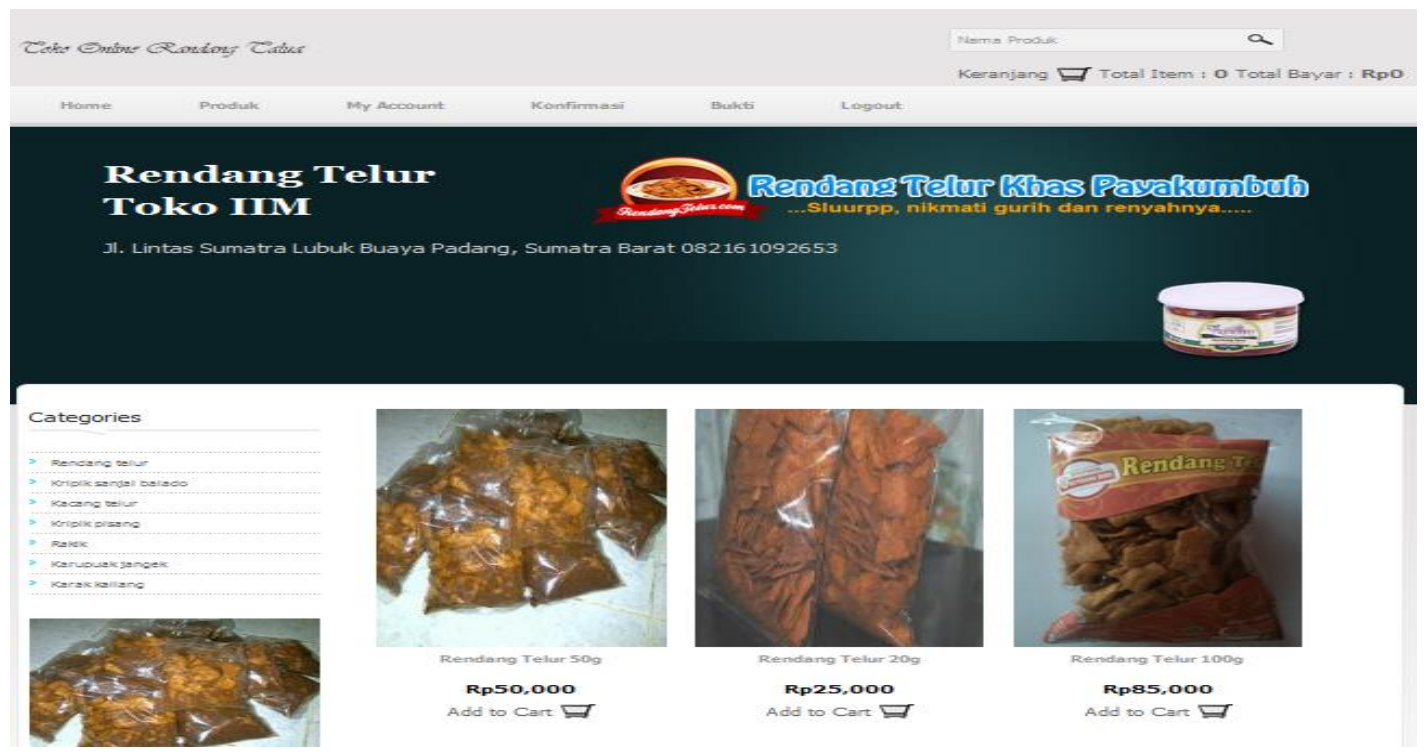

\section{Gambar 4.13Tampilan Home Pelanggan}

\section{Tampilan Produk Pelanggan}

Halaman produk pelanggan, pelanggan dapat melakukan pemesanan dengan mengklik pesan. Berikut gambar tampilan produk pelanggan yang dapat dilihat pada gambar 4.14 berikut ini:

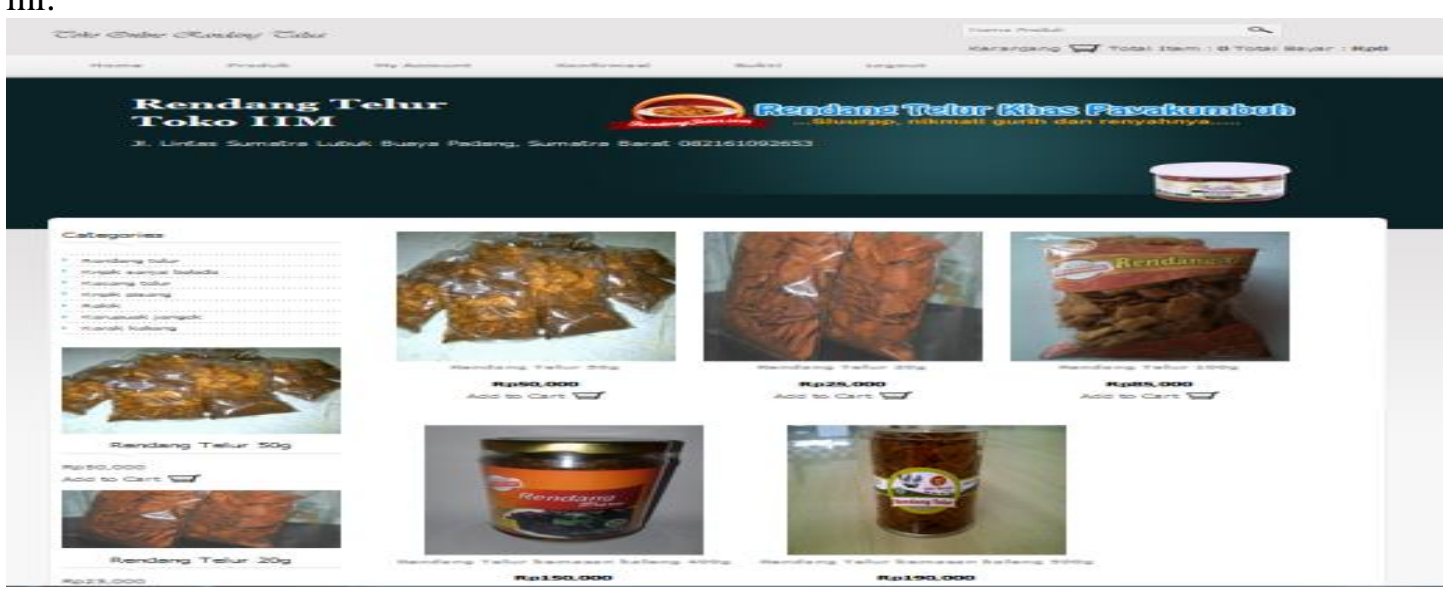

\section{Gambar 4.14 Tampilan Produk Pelanggan}

\section{Tampilan Keranjang Belanja}

Halaman keranjang belanja pelanggan dapat menentukan jumlah produk yang akan di beli, menghapus, dan selesai belanja. Berikut gambar tampilan Keranjang belanja yang dapat dilihat pada gambar 4.15 berikut ini: 
UPI YPTK Jurnal KomTekInfo Vol. 5, No. 1, Juni 2018, Hal.96-109 ISSN :2356-0010 | eISSN :2502-8758 Copyright@2018 by LPPM UPI YPTK Padang

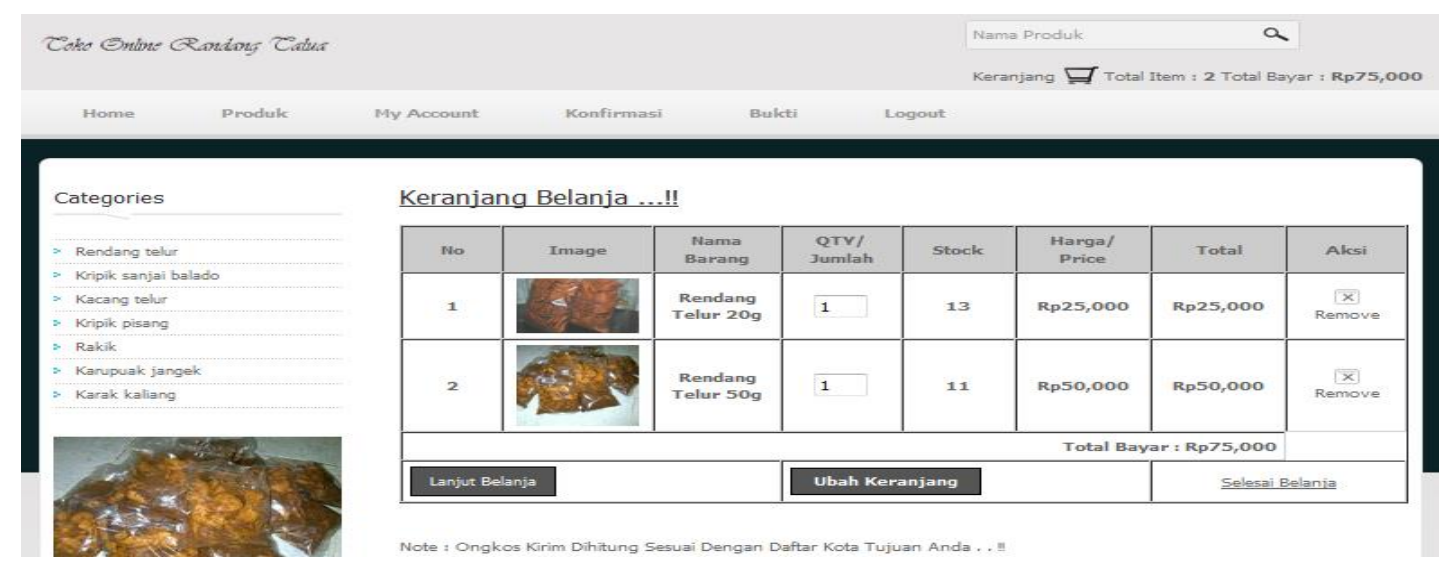

Gambar 4.15 Tampilan Keranjang Belanja

\section{Halaman Pembayaran}

Halaman pembayaran pelanggan memberikan bukti pembayaran. Berikut gambar tampilan pembayaran yang dapat dilihat pada gambar 4.16 berikut ini:

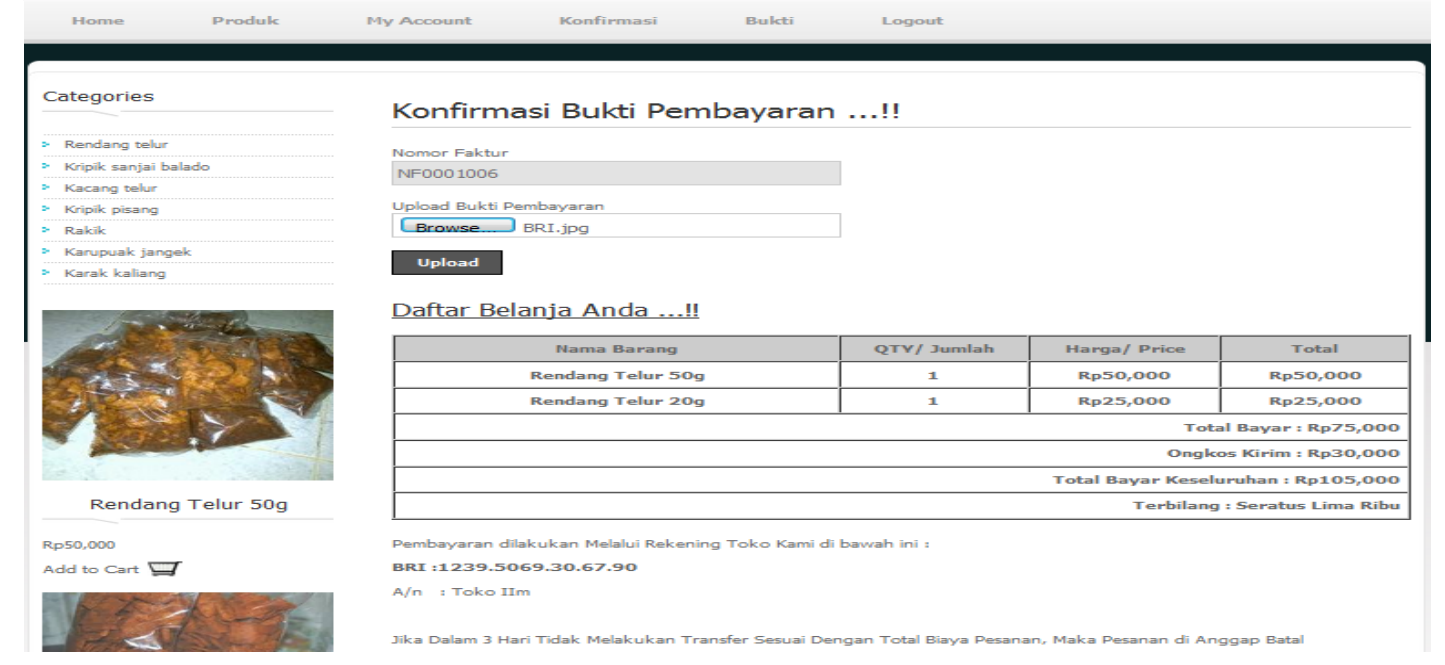

\section{Gambar 4.16 Halaman Pembayaran}

\section{Tampilan Edit Akun}

Halaman edit akun digunakan pelanggan untuk mengedit akunnya. Berikut gambara tampilan edit akun yang dapat dilihat pada gambar 4.17 berikut ini:

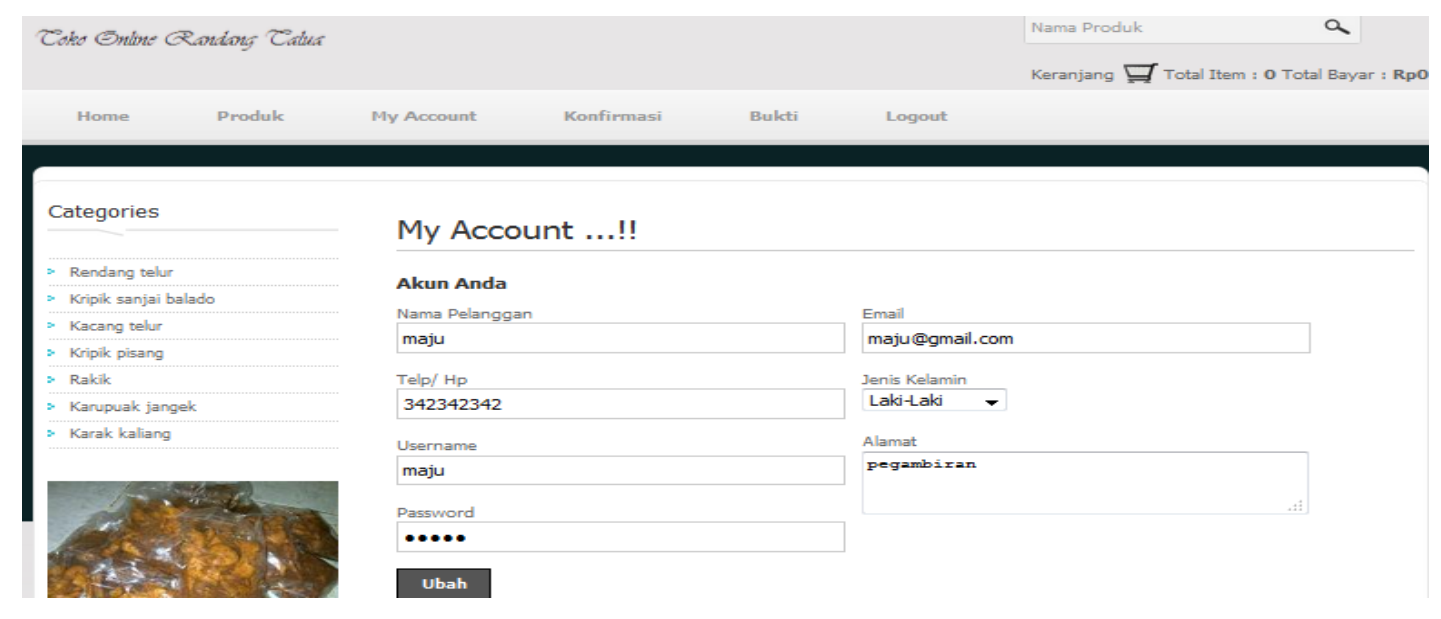


UPI YPTK Jurnal KomTekInfo Vol. 5, No. 1, Juni 2018, Hal.96-109 ISSN :2356-0010 | eISSN :2502-8758 Copyright $@ 2018$ by LPPM UPI YPTK Padang

\section{Gambar 4.17 Tampilan Edit Akun}

\section{Tampilan Cetak Bukti}

Halaman Cetak Bukti digunakan pelanggan untuk melakukan pencetakan bukti pemesanan dengan memilih nomor faktur yang ada. Berikut tampilan cetak bukti yang dapat dilihat pada gambar 4.18 berikut ini:

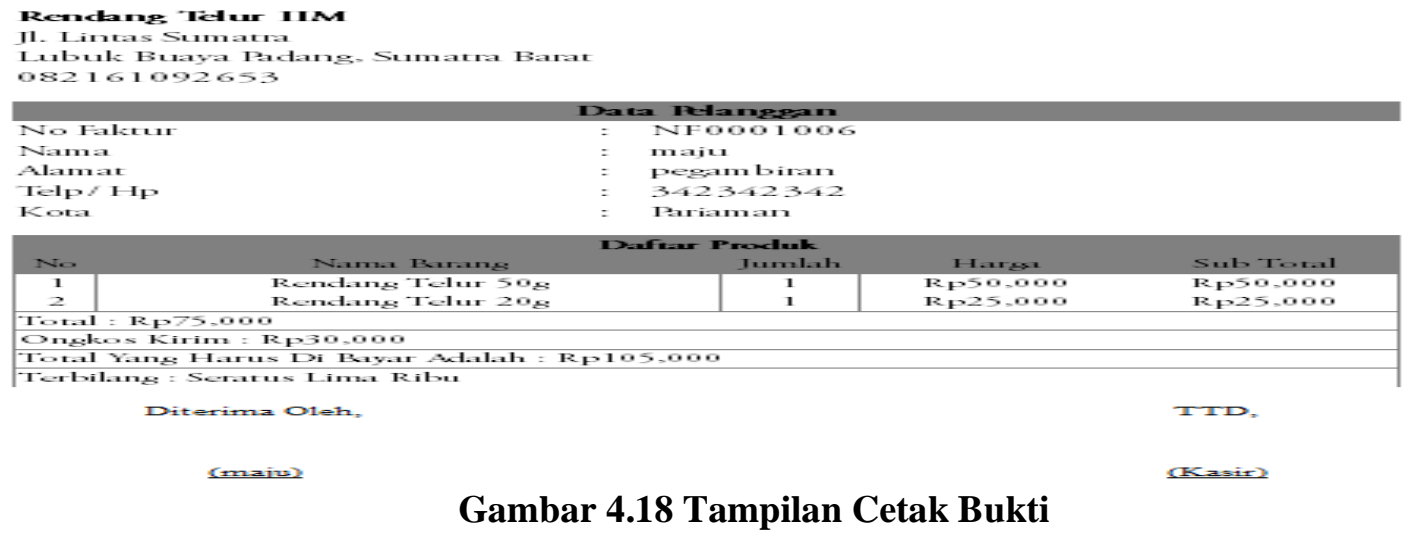

\section{Tampilan Laporan Perhari}

Halaman laporan perhari ini digunakan untuk mecetak laporan pemesanan perhari dapat dilihat pada gambar 4.25 berikut ini:

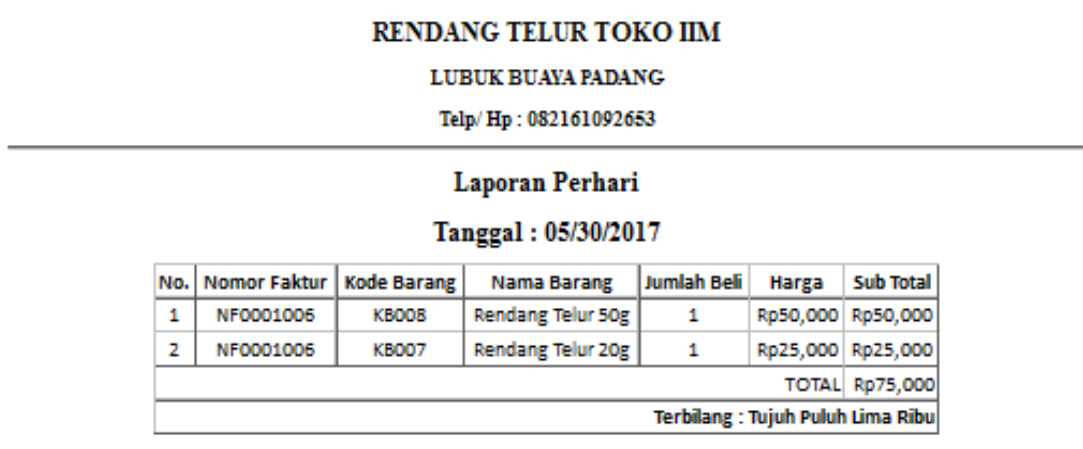

Penilik Toko Rendang Talua IIN

\section{Gambar 4.25 Tampilan Laporan Perhari}

\section{Tampilan Laporan Perbulan}

Halaman laporan perbulan ini digunakan untuk mecetak laporan pemesanan perbulan dapat dilihat pada gambar 4.26 berikut ini: 


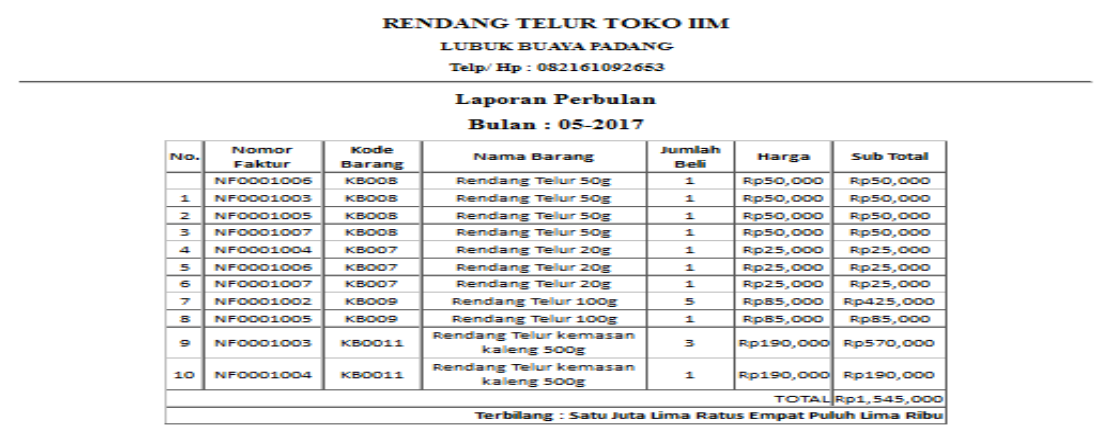

\section{Tampilan Laporan Pertahun}

\section{Gambar 4.26 Tampilan Laporan Perbulan}

Halaman laporan pertahun ini digunakan untuk mecetak laporan pemesanan pertahun dapat dilihat pada gambar 4.27 berikut ini:

\section{RENDANG TELUR TOKO IIM}

LUBUK BUAVA PADANG

Telp $/$ Hp : 082161092653

Laporan Perbulan

Tahun : 2017

\begin{tabular}{|c|c|c|}
\hline No. & Bulan & \multicolumn{2}{c|}{ Sub Total } \\
\hline 1 & May & Rp1,545,000 \\
\hline \multicolumn{2}{|c|}{ TOTAL } \\
\hline \multicolumn{2}{|c|}{ Terbilang : Satu Juta Lima Ratus Empat Puluh Lima Ribu } \\
\hline
\end{tabular}

\section{Kesimpulan}

Penilik Toko Rendang Talua ID.

\section{Gambar 4.27 Tampilan Laporan Perbulan}

Berdasarkan uraian yang telah dikemukakan pada bab terdahulu yaitu dari hasil penelitian yang telah dilakukan dengan mengunakan metode-metode penelitian maka dapat diambil kesimpulan sebagai berikut :

1. Perancangan aplikasi promosi dan pemesanan pada Toko Iim dapat mempermudah pelanggan dalam melakukan pemesanan Rendang Telur serta memperluas jangkauan pemesanan rendang telur diseluruh wilayah.

2 Aplikasi promosi dan pemesanan pada Toko Iim dapat mempermudah transaksi pemesanan Rendang Telur tanpa harus datang ke tempat lokasi

3 Aplikasi promosi dan pemesanan pada Toko Iim dapat meningkatkan ke untungan dan juga pembelian sehingga tidak merugikan Toko Iim dalam melakukan pemesanan secara online dan dapat memproses data maupun laporan dengan cepat tanpa harus takut terjadinya kesalahan-kesalahan informasi dan mampu membatu untuk menyimpan data supaya tidak tercecer atau hilang.

\section{DAFTAR PUSTAKA}

[1] A S, Rosa dan M. Shalahuddin. 2014. Rekayasa Perangkat Lunak: Terstruktur dan Berorientasi Objek. Bandung : Informatika Bandung.

[2] Ardhan,YM Kusuma 2014 project Php \& Mysql Membuat Website Buku Digital Purwokerto: Jasakom.

[3] Anggiani Septima Riyadi,Eko Retnandi,Asep Deddy,2012 "Perancangan Sistem Informasi Berbasis Website Subsistem Guru di Sekolah Pesantren Persatuan Islam 99 Rancabango " Volume 09, No.40, 2012 : 2302-7339. 
UPI YPTK Jurnal KomTekInfo Vol. 5, No. 1, Juni 2018, Hal.96-109 ISSN :2356-0010 | eISSN :2502-8758 Copyright $@ 2018$ by LPPM UPI YPTK Padang

[4] Anisya, agustus 2013 Aplikasi Sistem Database Rumah Sakit Terpusat Pada rumah Sakit Umum (RSU)'Aisyiah Padang Dengan Menerapkan Open Source (Php-Mysql) Volume 15, No.2, Agustusi 2013 : 1693-752x.

[5] Aris Setiyadi, Ramadhian Agus Triyono, januari 2014 "Pembangunan Website Ecommerce Dengan Sistem Informasi Transaksi Berbasis Sms Gateway Pada Toko Aska "Volume 3, No.1, Januari 2014 : 2302-5700.

[6] Guntur Wibisono, dan Wahyu Eko Susanto,2015 "Perancangan Website Sebagai Media Informasi Dan Promosi Batik Khas Kabupaten Kulonprogo"Volume3 No 2 -2015 lppm3.bsi.ac.id/jurnal.

[7] Hamim, Tohari. 2014. Analisis serta perancangan sistem informasi melalui pendekatanUML. ANDI. Yogyakarta 2014.

[8] Hidayatullah, Priyanto dan Kawistara Khairul Jauhari. 2014. Pemograman Web. Bandung: Informatika Bandung.

[9] Jilly Bernadette Mandey,desember 2013“Promosi,Distrubusi,Harga Pengaruhnya Terhadap Keputusan Pembelian Rokok Surya Promild" Volume 1, No.4, Desember 2013 : 2303 1174.

[10] Pratama, I Putu Agus Eka. 2014. Sistem Informasi dan Implementasinya. Bandung: Informatika Bandung.

[11] Pratama, I Putu Agus Eka. 2015.E-commerce,Ebusiness dan Mobile Commerce. Bandung: Informatika Bandung.

[12] Sutabri, Tata. 2012. Analisa Sistem Informasi. Yogyakarta: CV Andi Offset. 